Jacques Vergès, Rupture Strategy and the Argentinean New Left: Circulations and Adaptations of a Judiciary Theory

David Copello

ATER in Political Science, UFR Droit, Sciences Politiques et Sociales, Université Paris 13 Nord, Villetaneuse, France

Associate Researcher, CEVIPOF-Sciences Po (CNRS - UMR 7048)

david.copello@sciencespo.fr

The Version of Record of this article has been published and is available in Global Society, 2019, 33:3 https://www.tandfonline.com/10.1080/13600826.2019.1598943 


\title{
Jacques Vergès, Rupture Strategy and the Argentinean New Left: Circulations and Adaptations of a Judiciary Theory
}

\begin{abstract}
This article deals with the transatlantic circulations of the theory of "rupture strategy", popularized by French lawyer Jacques Vergès in the early 1960s. In the early 1970s, the concept was imported and adapted to the Argentinean context by radical left-wing lawyers. Their uses of rupture strategy were modelled by their perception of Argentina as being a "semi-colonized" country, whose situation was comparable to that of Algeria. In the 1980s however, in a context of democratization, the same lawyers reassessed their uses of "Vergesian" vocabulary and progressively renounced rupture strategy, while still maintaining a critique of liberal penal law. To account for this evolution, this article adopts a socio-historical perspective. It shows that the reception of Vergès' theory must be understood as a dynamic process, in which the permanent interaction and the contradictory evolution of two different contexts (context of reception and context of origin), interfere with the continued importation of rupture strategy.
\end{abstract}

Keywords: Jacques Vergès; Argentina; New Left; Political Justice; Circulation of Ideas.

\section{Introduction}

This article deals with the circulations of a theory of judiciary action between France and Argentina, and with the evolution of its uses between the 1960s and the 1980s. The theory and practice of rupture strategy were not invented in the 1960s: they came within the scope of preceding Leninist and anticolonialist conceptions of justice ${ }^{1}$, and had

\footnotetext{
${ }^{1}$ Liora Israël, L'Arme du Droit (Paris: Presses de Sciences Po, 2009).
} 
already been used by Argentinean lawyers since the $1930 \mathrm{~s}^{2}$. However, they were the object of a renewed interest from the 1960s onward, and were strongly popularized by Jacques Vergès, a media-friendly French lawyer involved in the defence of National Liberation Front (FLN) activists during the Algerian war of decolonization (19541962). ${ }^{3}$ The practice of rupture strategy as a juridico-political repertoire lawyers can use to face the authority of the tribunal was theorized by Vergès in a book called $D e l a$ stratégie judiciaire [On judiciary strategy], published in 1968. Vergès' theory is based on the distinction between rupture trials and connivance trials. According to him, "every characteristic of connivance trials espouses their fundamental need to respect the established order"4: connivance defence follows that rule and only aims at minimizing the punishment inflicted to the accused. On the contrary, "in most rupture trials, the aim of the defendant is not to obtain the acquittal of the accused, but to highlight his ideas."5 According to Vergès, this entails introducing politics into the tribunal arena, "leaving the domain of pure law, replacing the defence by the attack, and the courtroom by the

${ }^{2}$ Virginia Vecchioli, "Repertorios Militantes y Expertise Jurídica en la Defensa de la Causa de los Derechos Humanos en la Argentina: el Caso de la Liga Argentina por los Derechos del Hombre", Ensemble: Revista Electrónica de la Casa Argentina en París, no. 9 (2012).

3 Jacques Vergès (1925 - 2013), raised in La Réunion, studied law in Paris where he became familiar with the anticolonial Marxist milieu. He actively participated in the Algerian struggle for independence and became a prominent public figure during the trial of Djamila Bouhired, FLN bomber. See for instance: Sylvie Thénault, "Défendre les Nationalistes Algériens en Lutte pour l'Indépendance: la 'Défense de Rupture' en Question", Le Mouvement Social, no. 240 (2012), pp. 121-135. For more information on Vergès' trajectory, several non-academic biographies are available (see for instance:

Bernard Violet and Robert Jégaden, Vergès: le Maître de l'Ombre, [Paris: Seuil, 2000]) as well as a 2007 documentary by Barbet Schroeder, Terror's Advocate.

$4 \quad$ Jacques Vergès, De la Stratégie Judiciaire (Paris: Minuit, 1968), p. 31.

$5 \quad$ Ibid., p. 104. 
street." "6 Moreover, and although Vergès' argument is mainly concerned with defence strategy, he also considers his theory as relevant for accusation strategy. The key feature in both cases is that "the imposition of a sentence is not a matter of [juridical] principle, but of political convenience."7 The uses of this theory in a very different context, and the importation of Vergès' model into Argentina in the 1970s and 1980s raise two different sets of problems, linked to the issues of democratization and globalization.

The article first deals with the evolution of attitudes towards the judiciary sphere before and after democratization processes. Democratization has often been associated with the issue of (transitional) justice. ${ }^{8}$ However, the centrality of justice as an instrument of democratization should not result in underestimating its importance in the architecture of authoritarianism. Indeed, the practice of repression inside authoritarian regimes cannot be reduced to extra-judiciary action (forced disappearance, torture, summary executions, etc.). It is also made of legal aspects (as illegitimate as they may be considered): justice and judiciary courts can be active instruments of dictatorship ${ }^{9}$, which political opponents need to consider when building their own strategies. In other words: justice already was a space of political contention before democratization, but it has evolved in the process. How did this impact on the uses of judiciary theories such as rupture strategy in Argentina?

$6 \quad$ Ibid., p. 166.

$7 \quad$ Ibid., p. 121.

8 Sandrine Lefranc, "La Justice de l'Après-Conflit Politique : Justice pour les Victimes, Justice sans Tiers ?", Négociations, no. 24 (2015), pp. 101-116; Ruti G. Teitel, Transitional Justice (Oxford: Oxford University Press, 2000).

9 Tom Ginsburg and Tamir Moustafa (eds.), Rule by Law: The Politics of Courts in Authoritarian Regimes (Cambridge: Cambridge University Press, 2008). 
A second issue dealt with in this article is the association of globalization in Latin America with processes of liberal democratization rather than with revolutionary politics. Democratization has indeed often been presented as an opportunity for the importation of theories and strategies designed overseas. This line of research has shown the impact of exile and the transnational circulation of activists and intellectuals ${ }^{10}$ of the Argentinian New Left ${ }^{11}$ in the late 1970s on changes in political culture that strongly affected democratization processes a few years later. The focus on these actors as global players is thus linked with the decline of revolutionary expectations and the rise of liberal democratic perspectives. ${ }^{12}$ On the other hand, the previous transnational dynamics of revolutionary politics are generally presented as a

10 Sophie Baby, Olivier Compagnon, and Eduardo González Calleja (eds.), Violencia y Transiciones Politicas a Finales del Siglo XX: Europa del Sur-América Latina (Casa de Velázquez, 2009); Patrick William Kelly, "The 1973 Chilean Coup and the Origins of Transnational Human Rights Activism”, Journal of Global History, Vol. 8, no. 1 (2013), pp. 165-186. For Argentinean activists, see : Luciano Alonso, "Defensa de los Derechos Humanos y Cultura Política entre Argentina y Madrid, 1975-2005” (Santa María de la Rábida: Universidad Internacional de Andalucía, 2006); Marina Franco, El Exilio: Argentinos en Francia Durante la Dictadura (Buenos Aires: Siglo Veintiuno, 2008); Silvina Jensen, Los Exiliados: La Lucha Por Los Derechos Humanos Durante La Dictadura (Buenos Aires: Sudamericana, 2010); Pablo Yankelevich, Ráfagas de Un Exilio: Argentinos En México, 1974-1983 (México D.F.: Colegio de México, 2010). 11 Van Gosse, "A Movement of Movements: The Definition and Periodization of the New Left" in Jean-Christophe Agnew and Roy Rosenzweig (eds.), A companion to post-1945 America (Oxford: Blackwell, 2002), pp. 277 - 302; María Cristina Tortti, Adrián Celentano and Mauricio Chama (eds.), La Nueva Izquierda Argentina (1955 - 1976): Socialismo, Peronismo y Revolución (Rosario: Prohistoria, 2014).

Margaret E. Keck and Kathryn Sikkink, Activists beyond Borders: Advocacy Networks in International Politics (Ithaca: Cornell University Press, 1998); Nicolas Guilhot, The Democracy Makers: Human Rights and International Order (New York: Columbia University Press, 2005). 
less globalized phenomenon, as the continental scale is the privileged focus. ${ }^{13}$

Argentinean revolutionary movements are hence conceived as mainly influenced by Cuban Castroism, ${ }^{14}$ and the influence of African or Asian revolutionary movements on Latin-American politics, while being frequently mentioned, is rarely taken as an object of in-depth reflections. ${ }^{15}$ Although methodological nationalism has been challenged and partly overcome in the literature on the new revolutionary Left, the regional scale has prevailed over the global for the moment. Does it mean the global scale is irrelevant for the study of Latin-American revolutionary activism?

Studying the uses of rupture strategy in Argentina is the opportunity for a critical reflection on these two issues. First, rupture strategy is a judiciary repertoire used by revolutionary activists before democratization. Second, it is a good example of the intercontinental circulation of a repertoire associated with revolutionary politics. One way to combine these two issues is to assess the impact of democratization (in the 1980s) on the transnational circulation of Vergès' theory of rupture strategy, popularized in France in the 1960s and imported into Argentina in the 1970s.

Such a research topic implies a dialogue with a vast body of literature in contemporary social sciences, influenced by what has been termed a "circulatory

13 For exceptions, see: Alberto Martín Alvarez and Eduardo Rey Tristán, Revolutionary Violence and the New Left: Transnational Perspectives (New York: Routledge, 2017); Christine Hatzky, Cubans in Angola: South-South Cooperation and Transfer of Knowledge, 1976-1991 (Madison: University of Wisconsin Press, 2015).

${ }^{14}$ Dirk Kruijt, Cuba and Revolutionary Latin America: An Oral History (London: Zed Books, 2017).

15 Eugenia Palieraki, "De Pékin À La Havane : La Gauche Radicale Chilienne et Ses Révolutions, 1963-1970”, Monde(s), Vol. 1, no. 11 (2017), pp. 119-138. 
prism"16 that challenges diffusionist narratives of globalization, and takes the complex interactions between national and international settings into account. More specifically, this article elaborates on Pierre Bourdieu's analysis of "the social conditions of the international circulation of ideas"17 to assess the importation of rupture strategy into Argentina. Bourdieu's theory is mainly concerned with unidirectional circulations between two disconnected national fields (field of production and reception) through a triple process of adaptation: selection (What is being translated? What is not?), marking (Which publishing house? What preface writer?) and reading. This cross-national perspective is very useful when it comes to analysing the importation of Vergès' theory into Argentina. However, the entangled and transnational dimension of its circulation must also be enhanced, in line with post-Bourdieusian developments in the historical sociology of culture, to show that fields of production and reception are not necessarily separated but can sometimes be connected and intertwined by the transnational nature of the actors involved in the circulation. ${ }^{18}$ Moreover, to take a longitudinal perspective that would explain how uses of rupture strategy in Argentina evolved between the 1970s and the 1980s, another dimension must be taken into account: time, and the fact that

16 Antoine Vauchez, "Le Prisme Circulatoire : Retour Sur Un Leitmotiv Académique", Critique Internationale, Vol. 2, no. 59 (2013), pp. 9-16.

17 Pierre Bourdieu, "Les Conditions Sociales de La Circulation Internationale Des Idées", Actes de La Recherches En Sciences Sociales, no. 145 (2002), pp. 3-8.

18 Roger Chartier, La Main de l'Auteur et l'Esprit de l'Imprimeur : XVIe - XVIIIe siècle (Paris: Gallimard, 2015); Johan Heilbron, Laurent Jeanpierre and Nicolas Guilhot, "Vers une Histoire Transnationale des Sciences Sociales”, Sociétés Contemporaines, no. 73 (2009), pp. 121-145; Anna Boschetti (ed.), L'Espace Culturel Transnational (Paris: Nouveau Monde, 2010); Louis Pinto (ed.), Le Commerce des Idées Philosophiques (Bellecombes-en-Bauges: Croquant, 2009). 
"the use of a statement is conditioned by its previous interpretations". ${ }^{19}$ Only by combining these two dimensions of circulation (space and time) can we elaborate on Bourdieu's theory on the social conditions of the international circulation of ideas. Indeed, to understand the uses of rupture strategy in Argentina, the issue of importation must be conceived as a continued process rather than as a one-off event.

\section{Definition of the case-study}

To account for the evolutive circulation of Vergès' theory of rupture strategy, this article compares two different periods and two sets of trials. The most famous of them is the Juicio a las Juntas that took place in Buenos Aires in 1985. During this trial, 9 members of the ex-military juntas, that governed the country from 1976 to 1983, were judged by a civil court for gross human rights violations committed under their rule. This instance of transitional justice will be compared with an earlier set of trials that took place in the early 1970s, when Argentina was governed by another military dictatorship led by General Lanusse. ${ }^{20}$ These trials were designed by the ruling power to suppress revolutionary activism and the use of political violence by opponents. They targeted militants accused of murders, bank robberies or assaults on state officials, as well as mere members of alleged "subversive" groups such as Montoneros, ${ }^{21}$ the PRT-

${ }^{19}$ Thibaut Rioufreyt, "Les Passeurs de la 'Troisième Voie' : Intermédiaires et Médiateurs dans la Circulation Transnationale des Idées”, Critique Internationale, no. 59 (2013), pp. 33-46.

20 The political history of Argentina in the second half of the $20^{\text {th }}$ century is marked by a long series of coups d'État and dictatorships (1955-1958; 1962-1963; 1966-1973; 19761983).

${ }^{21}$ Montoneros was a Peronist armed organisation created in 1970. 
$\mathrm{ERP}^{22}$ or the FAR. ${ }^{23}$ Although they might have taken very different shapes, these two sets of trials shared a common characteristic: they were both designed to tackle the issue of political violence inside a judicial court. The 1980s trial against military juntas was thus an inverted reproduction of the 1970s trials against revolutionary militants. For the persons involved, it also acted as a reminder of their former positions and questioned the evolution of their doctrines and repertoires.

In the 1970s, the main promoters of rupture strategy in Argentina were militant lawyers, gathered around a lawyers' union, the Asociación Gremial de Abogados of Buenos Aires ${ }^{24}$, who had been strongly involved with revolutionary movements since the $1960 \mathrm{~s}^{25}$. Many of them were assassinated in the 1970s. Others quit active political action. Among the remaining lawyers, three of them (Eduardo Luis Duhalde, Carlos González Gartland and Rodolfo Mattarollo) kept working together in several human rights and leftist organisations and medias throughout the 1970s and $1980 \mathrm{~s}^{26}$. Their

${ }^{22}$ The Ejército Revolucionario del Pueblo [People's Revolutionary Army] (ERP), created in 1970, was the military branch of guevarist Partido Revolucionario de los Trabajadores [Workers' Revolutionary party] (PRT).

${ }^{23}$ The Fuerzas Armadas Revolucionarias (FAR) was a Marxist and Peronist armed organisation active between 1970 and 1973, when it merged with Montoneros.

${ }^{24}$ Gremial in further occurrences.

${ }^{25}$ Mauricio Chama, "Movilización y Politización: Abogados de Buenos Aires entre 1968 y 1973" in Anne Pérotin-Dumont (ed.), Historizar el pasado vivo en América Latina (Santiago: Universidad Alberto Hurtado, 2007), available: http://www.historizarelpasadovivo.cl/es_resultado_textos.php?categoria=Argentina\%3A+ el+tiempo+largo+de+la+violencia+pol\%EDtica\&titulo=Movilizaci\%F3n+y+politizaci\%F $\underline{3 n \% 3 A+a b o g a d o s+d e+B u e n o s+A i r e s+e n t r e+1968+y+1973}$ (accessed 3 September 2018); Mauricio Chama, "Peronización y Radicalización de Grupos de Abogados en los Años 60 y Principios de los 70: La Labor Defensista como Práctica Militante”, Cuestiones de Sociología, no. 3 (2010), pp. 143 - 168.

${ }^{26}$ For more detailed biographical data, please refer to the Appendix. 
trajectory is thus particularly illustrative of the evolving reception, adaptation and uses of Vergès' theory in the context of Argentinean political trials: it allows for a diachronic comparison. Three types of sources were used to reconstruct that trajectory: press interventions, interviews given by these lawyers and militant archives of the Gremial (collected at the National Library in Buenos Aires).

The results of this research are presented as follows. First, political violence trials in the 1970s are analysed to show how Vergès' theory of rupture strategy was introduced in Argentina by militant lawyers. Its declining uses and interpretations during the 1980s juntas trial are then retraced. Finally, the article shows that the comparison between the combined evolution of Vergès himself and of his introducers in Argentina can account for the decline in the uses of rupture strategy in Argentina among militant lawyers.

\section{Importing rupture strategy in the $1970 \mathrm{~s}$}

The introduction of Vergès' theory by militant lawyers in Argentina can be approached through a threefold interrogation. First: where was rupture strategy discussed in Argentina, what were its spaces of diffusion? Second: how was it understood and adapted by its importers? Third: why, on which political principles were these local adaptations based?

To account for the spaces of diffusion of rupture strategy, one of its crucial elements must be considered: the contestation of justice as an autonomous sphere. In Vergès' theory, judicial courts are mainly a soundbox for political causes, and the autonomous logic of trials is contested and/or undermined. Consequently, the diffusion of such ideas will be favoured in the field of justice if the latter is itself affected in its autonomous functioning. This was clearly the case in early-1970s-Argentina, where the authoritarian government led by General Lanusse created a special court for the 
judgment of political infractions. ${ }^{27}$ In the meantime, the security of lawyers involved with political activists was put at risk: in December 1970, Néstor Martins, a defence lawyer of leftist militants, was kidnapped by repressive forces together with one of his clients. In a context where justice was politicized by the state and the very practice of the profession was at stake, lawyers from the capital started to organize. Against the two existing lawyers" corporations, denounced as "apolitical", "bourgeois" and only concerned with "professional interests", ${ }^{28}$ a group of Peronist and Left-wing lawyers promoted the creation of the Gremial. The latter was based on two objectives:

Gathering law professionals for the defence of their guild interests, profoundly linked to the interests of our people. -

Projecting our action outside the trade union, by participating in the struggles that tend to give a solution to our serious national problems, by giving our professional and unionist support to all the oppressed sectors, whose rights and interests are permanently mocked and violated by those who are in power ${ }^{29}$

As can be seen from the previous quote, the autonomy of law as a professional field was clearly called into question by the Gremial. The practice of lawyering was thus directly connected to political activism, a fertile ground for the adoption of Vergès' views on rupture defence.

Débora D’Antonio and Ariel Eidelman, “iJuicio a los Revolucionarios! Represión Penal y Tribunal Especial del Poder Judicial en Argentina (1971 - 1973)”, Historia Crítica, no. 67 (2018), pp. 45-66.

Comisión Promotora de la Asociación Gremial de Abogados de la Capital Federal,

“Abogados de La Ciudad de Buenos Aires Invitamos a La Constitución de La Asociación Gremial de Abogados de La Capital Federal...”, August 1971 (Biblioteca Nacional, Buenos Aires; Fondo Centro de Estudios Nacionales - subfondo Silvio Frondizi, Box no. 7 - Asociación Gremial de Abogados). In what follows, all other sources located in the same archive will be referred to as coming from "BNBA".

Ibid. 
The creation of the Gremial reveals a politicization in the field of justice, while also creating new spaces of socialization for lawyers, such as courses and meetings. These gave ground to the diffusion of the theory of rupture strategy. Starting in June 1972, a 10-session course entitled "Fundamental aspects of political defence" was given by members Rodolfo Ortega Peña ${ }^{30}$ and Duhalde. ${ }^{31}$ During the National Meeting of Lawyers, organized by the Gremial in August 1972 and attended by around 300 lawyers, several presentations discussed the nature of defence strategies in political trials, explicitly quoting excerpts from Vergès' book. ${ }^{32}$ The Marxist view of law as ideology, mixed with different trends of anti-imperialism and Argentinean nationalism ${ }^{33}$, was highly influential in these discussions. It explains the insistence, within the debates, on the necessary connection between political trials and political struggles, to avoid the "liberal illusion" of law as an autonomous sphere. ${ }^{34}$ There was however no consensus on the status of justice and on defence strategies inside the Gremial, which gathered lawyers from very different political backgrounds. According to Mauricio Chama's research, the closer lawyers were to armed organizations, the

30 Rodolfo Ortega Peña, one of the most prominent members of the Gremial, was assassinated by paramilitary forces in 1974 .

31 Asociación Gremial de Abogados de la Capital Federal (Gremial), "Programa de Cursos", 31 May 1972 (BNBA).

32 Gremial, "Juicios Políticos Y Estrategias de Defensa En La Argentina de Hoy: Ponencia Presentada a La 'Reunión Nacional de Abogados’ Por La ‘Asociación Gremial de Abogados de La Capital"”, August 1972 (BNBA).

${ }^{33}$ These typical features of the Argentinean New Left might explain why earlier uses of rupture strategy by Argentinean lawyers were not considered in these discussions. Most of these local predecessors were members of the "old" Left whose legacy was strongly criticized by revolutionary activists of the 1960s and 1970s. There was thus a generational and political gap between early and late uses of rupture strategy among militant lawyers.

34 “Juicio Político Y Lucha Política En La Argentina de Hoy", August 1972 (BNBA). 
more supportive they were of rupture strategy and also, probably, of the importation of Vergès' theory - Ortega Peña and Duhalde being some of the leading figures in this trend. $^{35}$

How was rupture strategy understood and adapted to the Argentinean reality? The ideas of Vergès were not applied straightforwardly, and at least two elements altered its meaning and uses. Both recall Bourdieu's statement on the international circulation of ideas: "the sense and function of a foreign work are determined by the field of destination at least as much as by the field of origin." 36

First, uses of Vergès were marked by its importation through Spain. Indeed, in interventions at the National Meeting of Lawyers, his theory was presented with quotes from the Spanish edition of his book, made by an independent publishing house from Barcelona. ${ }^{37}$ It therefore seems that rupture strategy was not imported directly from France and was rather read through a Spanish prism. This can be explained by linguistic barriers, but also by the simultaneous uses of rupture by Basque nationalists against Francoist judges. References to Vergès were actually mixed with references to another book, written by one of the lawyers of the ETA in the Basque Country. ${ }^{38}$ Both texts were probably circulated and read jointly. Vergès' theory was hence included in a larger stream of texts. This created an effect of "marking", already mentioned by Bourdieu for the publishing world:

\footnotetext{
${ }^{35}$ Mauricio Chama, "Compromiso Político y Práctica Profesional a Principios de los Setenta: el Caso de la Asociación Gremial de Abogados”, Sociohistórica, no. 7 (2000), pp. 81-107.

36 Bourdieu, op. cit., p. 4.

37 Jacques Vergès, Estrategia Judicial En Los Procesos Políticos (Barcelone: Anagrama, 1970).

38 Kepa Salaberri, El Proceso de Euskadi En Burgos: El Sumarísimo 31/69 (Paris: Ruedo Ibérico, 1971).
} 
With the insertion in a [publishing] collection, the adding of a preface, with the content of the preface, but also because of the position occupied by the preface writer in the [social] space, a series of transformations, or even distortions of the original message are being operated. ${ }^{39}$

ETA lawyers were in favour of an adaptation of Vergès' principles, considering the diversity of national realities. They promoted a strategy of "false connivance" or "masked rupture" that the Gremial took over and defined in the following terms:

It is a trial that looks like a connivance trial [but] in which the defence, due to circumstances, only hides its total dissidence towards the system. The situation [sic] between the tribunal and the defence is that of a rupture trial, but the trial takes place peacefully and rupture is not performed. ${ }^{40}$

Secondly, and more simply, Argentinean uses of rupture strategy allowed for a more pragmatic approach of judiciary strategy. In fact, the choice of a strategy highly depended on the nature of the charges, on the personality of the accused and on potential flaws in the procedure. The leader of an armed organization, for instance, was doomed from the start and could not be defended as an anonymous militant would. Likewise, someone accused of murdering a high ranking official and someone only suspected of carrying guns or of being member of an unlawful association would not be defended with the same strategy. As Mattarollo put it, "when a light sentence was attainable, you had to go for it. But in some cases, this was not possible, so you had to blow it all to hell." ${ }^{41}$ In other words, when a light sentence was possible to attain, lawyers would privilege a rather technical and connivance kind of defence. But when it was sure that, whatever happened during the trial, the heaviest punishment would be

\footnotetext{
39 Bourdieu, op. cit., p. 6.

40 Gremial, "Juicios Políticos Y Estrategias de Defensa En La Argentina de Hoy", op. cit.

41 Asociación Memoria Abierta, Interview with Rodolfo Mattarollo, 2003.
} 
sentenced, then lawyers could use a more radical rupture strategy: they had nothing to lose. ${ }^{42}$ In the Sallustro case, ${ }^{43}$ Mattarollo obtained the acquittal of his client on the charge of murder, by insisting on the flawed procedure (the accused had confessed under torture). In the Sánchez case ${ }^{44}$ however, the accused were in a more seriously compromised position, and their lawyers opted for a purer rupture strategy: they denied the authority of the tribunal, which they deemed unconstitutional because it was designed to pursue political infractions, and laid claim to the right to rebellion against a tyrannical regime. ${ }^{45}$

On which grounds of legitimacy could a judiciary technique elaborated in a (completely) different context be used to serve Argentinean political struggles? And once that strategy was adopted, according to which principles could such a pragmatic adaptation be defended?

It is worth mentioning that although Argentina had been an independent State since the early $19^{\text {th }}$ century, a large part of the Left in the 1960s and 1970s considered Argentina and Latin America as a semi-colony of foreign Anglo-Saxon capitalism, and identified with anticolonial struggles. The complex building of that "imagined community", which can only be evoked here, gave rise to a strong interest for the Algerian war of decolonization and a widespread diffusion of anti-colonial authors,

${ }^{42}$ For more details and testimonies, see: Memoria Abierta, Abogados, Derecho y Política (Buenos Aires: Memoria Abierta, 2010).

43 Oberdan Sallustro, director of Fiat Argentina, was kidnapped by the ERP in March 1972 and later executed during a police raid.

44 In April 1972, Juan Carlos Sánchez, Commander of an Army Corps in the Province of Santa Fe, was assassinated by a joint commando of the ERP and the FAR.

45 Laura Saldivia, Derechos Humanos Y Derecho de Interés Público En Argentina: ¿Quiebre O Continuidad? (Buenos Aires: Facultad de Derecho - Universidad de Palermo, 2003), pp. 19-21. 
Vergès being only one possible example among others. ${ }^{46}$ In this context, the analogy between Argentinean activists in prison and Algerian militants tried by French courts probably seemed appealing in the eyes of militant lawyers,.

However, being semi-colonized was different from being merely colonized, and this bore consequences on the way the judiciary system was perceived, and rupture strategy interpreted. This resulted in a "reading operation", in which readers apply "categories of perception and issues that are the product of a different field of production" from the field of origin of the theory. ${ }^{47}$ In an article published in 1971, Duhalde and Ortega Peña argued for a judiciary strategy that would mix rupture and connivance, a technique they justified on the grounds of the specific political situation of Argentina:

Every revolutionary political strategy whose main point of reference is the juridical question is doomed to failure because of its reformism. That makes no doubt. However, it is dialectically true that the semi-colonial situation [of Argentina] prevents the judiciary apparatus from being totally aligned with repression, as bearers of the System would like it to be. ${ }^{48}$

In a fully colonial situation, the tribunal doesn't need to simulate independence. In a semi-colonial situation, it does. According to Duhalde and Ortega, that was the reason why Argentinean judges could not act as toughly as military governors and foreign corporations would have liked them to: their position required to perform the illusion of

46 For another example, see: Alejandro De Oto, "Usos de Fanon: Un Recorrido Por Tres Lecturas Argentinas", Cuyo: Anuario de Filosofía Argentina y Americana, Vol. 30, no. 1 (2013), pp. 35-60.

47 Bourdieu, op. cit., p. 5.

48 Eduardo Luis Duhalde and Rodolfo Ortega Peña, "Justicia Del Sistema Y Situación SemiColonial", Cristianismo Y Revolución, no. 23 (1971), pp. 19 - 23. 
autonomy. Therefore, militant lawyers could exploit these internal contradictions of "the System", by using connivance defence as long as it was possible and effective, and rupture defence whenever it was politically relevant.

Although it was adapted to this local context, the reference to Vergès and rupture defence was central in the praxis of militant lawyers in the 1970s.

\section{A complex relationship to rupture strategy in the 1980s}

The 1970s and 1980s were a particularly turbulent time in Argentinean history. As mentioned previously, the country was ruled by a military dictatorship in the early 1970s. After a brief democratic interlude (1973-1976), another coup d'État took place: most militant lawyers of the previous period were killed or forced to exile. They would return to Argentina only in 1983, after the military call for elections. For some of these actors, there was no going back from this professional interruption: Duhalde and Mattarollo stopped serving as lawyers for good, and González Gartland started to make a living essentially on private law cases. However, they were still active in politics, and contributed to the Left-wing press on a very regular basis in the 1980s. Their treatment of the military juntas trial (April - August 1985) in opinion articles published in reviews such as El Periodista de Buenos Aires (a Left-wing weekly news magazine), Madres de Plaza de Mayo (a monthly newspaper sponsored by the homonymous organization) and Entre Todos (a Left-wing nationalist monthly magazine) illustrates the evolution of their relation to rupture.

Strikingly, the discussion of rupture strategy that used to be so important in the 1970s, almost disappeared in this set of articles in the 1980s. Out of these three actors, Mattarollo was the only one who referred explicitly to it, and he did so in only two occasions. In June 1985, he noticed that military defenders were trying to exploit some sort of rupture strategy against their civil accusers and criticized their misinterpretation 
of this judiciary strategy. According to him, these lawyers tried to "“"politicize" the trial by treating witnesses and complainants as if they were the accused". ${ }^{49}$ In doing so, they clearly reminded of the theory of rupture trials elaborated by Vergès, in which "the accused chooses to confront the tribunal and the applicable law" instead of "playing the game. ${ }^{, 50}$ Nevertheless, Mattarollo considered this use of rupture strategy as incorrect:
Not only do they hesitate between "rupture" and "connivance", but even when they try to politicize the debate, they stop half way. And this is inevitable. "Rupture trial" is not only the contestation of an "unjust" law and a partial court, it is also the assumption that your own cause is legitimate. That is something the main responsible of crimes against humanity such as disappearances, tortures and summary executions cannot do ${ }^{51}$

According to Mattarollo, there was a huge difference between what military lawyers were doing and what Vergès had recommended. For the latter, defending a person entailed giving full support to his or her cause, which was impossible here, because what was judged in the juntas trial was a reactionary form of state terrorism, not an emancipation struggle. Up to this stage, Mattarollo still tried to protect Vergès' theory from an alleged incorrect interpretation. Five months later however, in November 1985, the distinction between a good and a bad interpretation of Vergès was not so clear anymore. In one article, he denounced "the old sophistic tactic that consists in inverting the situation, in order to transform the accused into an accuser." 52 In doing so, he did not distinguish Vergesian strategy from its inaccurate application anymore. The

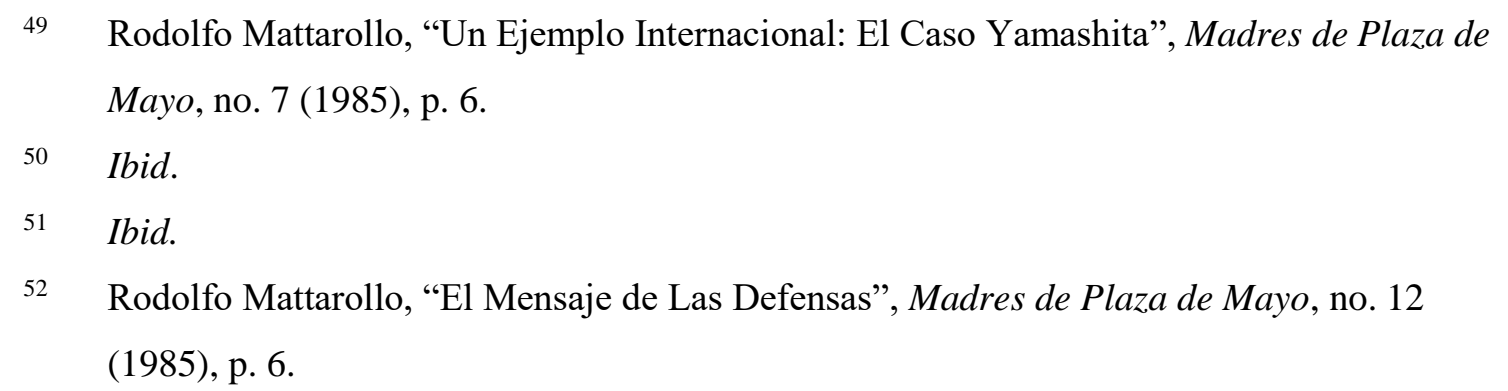


"sophistic tactic" he argued against was actually a pretty good definition of what rupture strategy is about. How to account for this quick evolution that goes from a scarce but principled defence of Vergès' theory against some of its uses, to its complete dismissal?

A certain amount of changes in the local context could explain the declining trajectory of rupture strategy in Argentina. While militant lawyers used to be on the side of the accused in the 1970s, they were now supporting the accusation. This made any attempt to delegitimize the judicial institution less attractive, because it could have simply undermined punishment of a political enemy. But this change might also be related to the renewed autonomy of the field of law. In the 1970s, the diffusion of Vergès' theory had been favoured by the existence of socializing spaces like the Gremial that connected the field of law with the field of politics. In the 1980s, these spaces had disappeared, and their specific repertoires of contention did not fit the social strategies of legal actors anymore. What prevailed in the 1980s was a depoliticized vision of law incarnated by NGOs such as Amnesty International (at the global level) and by President Alfonsín's promotion of individual rights (at the national level), downplaying the socio-economic dimensions of justice. These were good incentives for lawyers to abandon rupture strategy and to revive the tradition of liberal penal law. Mattarollo firmly pointed to this direction:

To fight against the subversive threat, the state can recur to repressive methods that are criminal themselves. Supporters of this pseudo-theory, enrolled in the so-called "law and order" movement, have been overwhelmingly refuted by the liberal juridical doctrine that is the foundation of modern penal law and has been a conquest of the western world for two hundred years ${ }^{53}$

53 Rodolfo Mattarollo, "El Ataque de La Defensa", El Periodista de Buenos Aires, no. 39 (1985), p. 7. 
Against the political justification offered by the military defence, Mattarollo opposed the impartiality of liberal law.

However, Duhalde, González Gartland and Mattarollo were no supporters of the government's justice policies and of a depoliticized conception of human rights. The desire to politicize the trial was still present among them. They actually regretted that the accusation was built exclusively on juridical arguments and did not take the political and social nature of the judged matter into account. For Mattarollo, the trial of the dictatorship should not have been limited to the direct military responsible of mass murders but should have also included indirect responsibility of civilian state officials:

There is a missing dimension in our current system based on liberal juridical formalism. There is an empty space on the bench of the accused [...]: that of Martínez de Hoz. ${ }^{54}$ It would indeed be vain to go to court against the main persons responsible of state terrorism without taking the objectives they were pursuing into account [and without involving] the ministry of Economy of the dictatorship, who destroyed the productive apparatus and drowned the country in an abyss of speculation ${ }^{55}$

For Mattarollo, liberal penal law was necessary but not enough, because it did not get involved with the economic, social and political dimensions of repression. For Duhalde, the apolitical stance of the tribunal hid a political purpose:

We already started to hear, in the backyard of the tribunal, some people trying to shorten the trial, under the argument that "we do not need to accumulate so many

$54 \quad$ Ministry of Economy from 1976 to 1981.

55 Rodolfo Mattarollo, “Que La Tortilla Se Vuelva”, Entre Todos Los Que Queremos La Liberación, no. 6 (1985), p. 5. 
proofs, for guilt is already proven", so as to prevent the country from realizing the dimension of the genocide ${ }^{56}$

Duhalde went on and distinguished two aspects of the trial: a "purely proceduraljuridical" dimension, and an "essentially political" ${ }^{57}$ one. By privileging the first of these two, advocates of a purely juridical trial undermined its political value, which was more important in Duhalde's eyes. Finally, the sentence pronounced against the 9 leaders of the military juntas was considered disappointing by these militant lawyers: among the accused, only two were sentenced to life imprisonment, and there were four acquittals. According to González Gartland, this sentence provoked "a collapse of the hope to build democracy without a frontal opposition to dependent capitalism." 58 Liberal law was thus connected to liberal economy, and both were strongly criticized:

Justice is based on a specific economic and social model. That is the reason why nobody seriously believes in its absolute impartiality. But in this case, what is questioned are the impartial rules of the game themselves. They had been accepted and are now being infringed upon ${ }^{59}$

Liberal penal law was accepted and at the same time strongly criticized, because justice was considered to be always political. Although, for tactical reasons, rupture defence was rejected during the juntas trial, the politicization of the trial was not completely unwelcome: it was even considered insufficient in the light of the sentence. Although the reference to Vergès declined, as well as the repertoire of rupture defence, militant de Mayo, no. 7 (1985), p. 7.

Ibid.

58 Carlos González Gartland, "De Sentencias Y Puntos Finales”, Madres de Plaza de Mayo, no. 14 (1986), p. 4.

Ibid. 
lawyers seemed to advocate for a sort of rupture accusation, in which "the imposition of a sentence is not a matter of [juridical] principle, but of political convenience." 60

The political critique of liberal penal law was thus not eradicated, but the repertoire of rupture trials was not explicit anymore, and Vergès was no longer a relevant intellectual figure to be mentioned. The local context is however not sufficient to account for this evolution: the interaction between national and extra-national realities must also be taken into account.

\section{Combined contexts interfering in circulation}

Meaning is affected by context. Theories are designed by social actors and associated with them. Therefore, the social position of theorists affects the way the content of their theory is understood and interpreted. The philosophy of Heidegger has for instance been considerably re-evaluated once the strength of his support to Nazism was reassessed: it is now difficult to interpret his work autonomously, without taking his political engagement into account. ${ }^{61}$ Importantly, the connection between theory and context is not limited to the time of publication: theories are always read under the light of their authors' biography, and interpreted according to the individual evolution of theorists. Although anachronic in terms of historical understanding, this is a powerful social mechanism.

The same logic affects our understanding of Vergès' theory of rupture. In the 1960s, he was clearly associated with a Left-wing anti-colonialist stance, exemplified by his defence of FLN prisoners. But the political implications of his theory started to blur seriously in the 1980s. In January 1983, the former SS officer Klaus Barbie was

\footnotetext{
$60 \quad$ Vergès, De la Stratégie Judiciaire, op. cit., p. 121.

61 Pierre Bourdieu, L'Ontologie Politique de Martin Heidegger (Paris: Minuit, 1988).
} 
captured in Bolivia and extradited to France. He was accused of being responsible for the deportation of hundreds of Jews in occupied France during the Second World War and charged with crimes against humanity. Barbie appointed Vergès as his lawyer. ${ }^{62}$ This was a major turn in Vergès' career, who would later defend Slobodan Milosevic and several other state leaders involved in international crimes, thus gaining the nickname “terror's advocate". In 1983, Vergès justified his acceptance of Klaus Barbie's defence on mainly political grounds:

Since I started to work on this case, I have received many letters from colleagues, from many Arab countries, from many countries in Black Africa, that say "bravo", you were right, and if you want us to give you a hand, here we are, here we are because we are tired of all these distraction trials, we are tired of saying that crimes against humanity, Hitler did them, and only him, we are tired of seeing that Mi-Lâ̂ massacre in Indochina is being forgotten, we are tired of forgetting the million dead people in Algeria, we are tired of forgetting Dar-Yacine, Fafir Kassem, Sabra and Chatila; we are tired, we are being hidden because we're niggers. And that's the problem in fact: through this trial, for something that occurred in 1944, they want to deny what has been done in 1954 or in $1964^{63}$

Through the defence of a former Nazi officer, Vergès thus made a political point. He claimed to highlight the fact that similar crimes, committed by western colonial powers, were not being judged. By defending Barbie, Vergès wished to denounce what he considered to be a double standard in justice and memory processes.

This raises the following question: what was the effect of the French context on the Argentinean context, of French uses of rupture on Argentinean uses of rupture? The situation was in fact more complex, because the Barbie affair cannot be reduced to a

62 Jacques Vergès, Je Défends Barbie (Paris: Jean Picollec, 1988).

63 Jacques Vergès and Etienne Bloch, La Face Cachée du Procès Barbie (Paris: Samuel Tastet, 1983), p. 30. 
mere national context. The trial itself involved transnational actors in its very development: the accused was a German citizen, extradited from Bolivia, judged by a French court and defended by three lawyers of different nationalities (Vergès, the Algerian Nabil Bouaita, and the Congolese Jean-Martin Mbemba). Furthermore, from the Argentinean militant lawyers' point of view, France was not a purely external reality. During the dictatorship years, part of their activism against the ruling regime had taken place in Paris. Mattarollo, in particular, had been a permanent resident and an active political actor in France from 1975 to 1983. During these years, he had built strong connections with Third-Worldism and humanitarian activism in Paris. He had also become a regular contributor to the journal Le Monde Diplomatique and was aware of the French political news. ${ }^{64}$ To some extent, it could be said that, for Mattarollo at least, the French context was perceived as his own. It was not a neutral reality for Argentinean militant lawyers and should rather be considered, paradoxically, as part of the Argentinean context itself. Here, the assertion of Bourdieu, according to which "texts circulate without their context" ${ }^{65}$ must be taken with caution. In this instance, it is partly incorrect because the French and Argentinean scenes should not be considered as "self-sufficient universes" but rather as "specific configurations embedded in a wide range of transnational relationships." ${ }^{\circ 6}$ Sensitive to the French context, Argentinean lawyers experienced difficulties with Vergès' evolution. In his analysis of the Barbie defence in 1987, Mattarollo directly denounced 'Jacques Vergès' confusionist

In 1987, El Periodista de Buenos Aires even sent him as a special correspondent to cover the Barbie trial in France.

65 Bourdieu, "Les Conditions Sociales de La Circulation Internationale Des Idées", op. cit., p. 4.

${ }^{66}$ Heilbron, Guilhot and Jeanpierre, op. cit., p. 123. 
manœuvre that consists in [...] putting the holocaust of the Third Reich into perspective through the martyr of the Palestinian people and the colonial African peoples."67 Consequently, explicit uses of his theory by Argentinean militant lawyers declined in the 1980s, after a few hesitations.

In the meantime, dominant symbolic frames had evolved in Argentina since the early 1970s, making it even more difficult for lawyers and activists to align with Vergès. As previously mentioned, Argentinean revolutionary movements of the 1970s conceived themselves as part of a wider anticolonial international trend. During that period, military governments were considered as an occupying force, following orders from imperialist countries (the USA or the United Kingdom) and foreign corporations. Progressively however, repressive policies implemented by the Argentinean military tended to be compared also to Nazi massacres. This corresponded to a period in time, the late 1970s and early 1980s, when the remembrance of the Holocaust globally reappeared on the public scene. ${ }^{68}$ At the same time, the massacre of Argentinean political opponents between 1976 and 1983 started to be conceptualized as genocide by political actors and human rights organizations. ${ }^{69}$ The analogy between the Argentinean dictatorship and the Nazi regime was reinforced by the insistence on the xenophobic

Rodolfo Mattarollo, “Una Lección de la Historia”, El Periodista de Buenos Aires, no. 148 (1987), p. 16. Enzo Traverso, L'Histoire Comme Champ de Bataille: Interpréter les Violences Du XXe Siècle (Paris: La Découverte, 2011).

Emilio Crenzel, "The Crimes of the Last Dictatorship in Argentina and its Qualification as Genocide: a Historicization", Global Society, Vol. 33, no. 3 (2019); Luciano Alonso, "La Definición de las Ofensas en el Movimiento por los Derechos Humanos en Argentina y la Calificación de 'Genocidio", Contenciosa, no. 1 (2013), available:

$<$ http://www.contenciosa.org/sitio/verarticulo.aspx?i=8> (accessed 11 May 2018). 
and anti-Semitic dimension of repression in reports of non-governmental agencies, ${ }^{70}$ and reproduced in the Nunca Más report of the truth commission appointed by the elected government in $1983 .{ }^{71}$ Anti-nazism was now part of the discursive opportunity structure of social movements in Argentina. Consequently, when the juntas trial was about to start in 1985 , the Argentinean press regularly compared it to the Nuremberg trials organized in post-war Germany. ${ }^{72}$ This does not mean that anti-imperialism had disappeared from the ideological landscape of the Argentinean Left. In fact, antiimperialism and anti-Nazism seemed to go hand in hand in its new discursive repertoire of contention. One good example of this articulation is the title of a book of denunciation published a few years later by Alipio Paoletti, a close collaborator of Mattarollo, Duhalde and González Gartland: Como los Nazis, como en Vietnam [Just like the Nazis, just like Vietnam]. ${ }^{73}$

There was thus a clear contradiction in the simultaneous evolution of symbolic frames in the case of Vergès and in the case of militant lawyers in Argentina. While Vergès took a sulphurous stance against anti-Nazism in the name of anti-colonialism, Argentinean militant lawyers made a parallel between anti-Nazism and antiimperialism. In one case, anti-Nazism opposed anti-colonialism, in the other they converged. This de-alignment became a clear obstacle to the continued importation of rupture strategy in Argentina, although none of the actors involved would have claimed

70 CADHU, Argentina: Proceso al Genocidio (Madrid: Elías Quejereta, 1977).

71 Comisión Nacional Sobre la Desaparición de Personas, Nunca Más: Informe de la Comisión Nacional sobre la Desaparición de Personas (Buenos Aires: EUDEBA, 1984).

72 Carlos González Gartland, "Nüremberg Y La Plaza Lavalle”, Madres de Plaza de Mayo, no. 6 (1985), p. 5.

73 Alipio Paoletti, Como los Nazis, Como en Vietnam: Los Campos de Concentración en la Argentina (Buenos Aires: Contrapunto, 1987). 
that his views on justice had fundamentally changed. Simply, the combined evolution of multiple contexts created a gap: rupture strategy was not fit anymore for Left-wing militant lawyering in Argentina. Actors like Mattarollo might have tried to reconcile their past uses of rupture strategy with their contemporary political position, but this was rendered very difficult by the actions of Vergès himself. Although nothing had changed in the text of his theory itself, its implications and the meaning attached to it had evolved because of how its author had subsequently used it.

\section{Conclusion}

This research on the importation of Vergès' strategy of rupture in Argentina has confirmed that, even before the democratizing period of the $1980 \mathrm{~s}$, the issue of political violence was already associated with law, and that revolutionary politics were already included in a global space of circulations in the 1970s. Tracking the uses of rupture strategy in the post-dictatorship years also helped understanding how the evolution of the political context, marked by a democratization process, impacted on the political imaginaries and ideological repertoires of political and legal actors. However, these local developments proved insufficient to account for the striking disappearance of Vergesian rupture strategy among militant lawyers. The issue was hence addressed by observing the interaction between the French and Argentinian local contexts and the contradictory evolution experienced in anti-imperialist militant lawyers' repertoires of contention. These observations shed light on the clear de-alignment of frames that damaged the continued importation of Vergès' theory in Argentina, and ultimately led to its abandonment. The articulation between the 1970s activism and the 1980s democracy making, two periods that are often disconnected in the study of South Cone politics, could prove productive to analyse other cases of democratization in which former revolutionary activists are involved, to provide a more nuanced understanding of 
transitional processes by insisting on the trajectories of involved actors.

The study of the uses and interpretations of Vergès' theory in Argentina shows that its importation must be considered as more than a one-off event. It is obviously a dynamic process, because uses of the imported theory vary according to the evolutions of the context of reception. But this dynamic process is also multidimensional: uses of the theory depend on the evolutions in the context of reception as well as on the transformation of the context of origin (provided that the two can be separated). The importation of rupture strategy therefore needs to be considered as a continued process, its uses being modelled by a constant (or at least regular) interaction between a context of origin and a context of reception. By taking an entangled and longitudinal perspective on importation, these observations bring intellectual tools to enhance Bourdieu's theory on the circulation of ideas in a globalized framework, without renouncing to his importation/exportation standpoint and to his analysis in terms of selection/marking/reading, which remains very heuristic. The circulation of justice paradigms across the globe is thus neither a history of diffusion and universalization, nor a history of independent processes of importation based on national scales. It is a complex reality, in which multiple dimensions of time and space are intertwined.

\section{Acknowledgments}

The author would like to thank Sophie Baby, Raluca Grosescu, Laure Neumayer, Haley McAvay and the two anonymous reviewers for their useful comments and suggestions on earlier versions of this article. 


\section{Appendix: Three militant lawyers' trajectories}

Eduardo Luis Duhalde (1939 - 2012) graduated in law from the Universidad de Buenos Aires (UBA). He became a prominent Peronist intellectual, journalist and lawyer of political prisoners in the 1960s. He was a member of the Gremial from its creation in 1971. In 1975, he became the leader of a small armed organization called Partido Revolucionario de los Obreros Argentinos (PROA). In 1976, he was at the head of newly created Comisión Argentina de Derechos Humanos (CADHU), which he directed from his exile in Madrid. A leading figure among Leftist human rights activists in Argentina, he collaborated to many reviews in the 1980s, and in 1989 he was appointed as a director of Nuevo Sur, a journal funded by the communist party. In the meantime, he created a think tank called Instituto de Relaciones Internacionales (IRI) and Izquierda Democrática Popular (IDEPO), a new Left-wing party opposed to the government of Alfonsín, with small electoral results but high influence on the remaining networks of the New Left. After the party was dissolved in 1991, he left active politics and was appointed as a judge. In the early 2000s, he built strong connections with Néstor Kirchner who named him Secretary of State for Human Rights when he was elected president in 2003. Duhalde kept this position until his death in 2012.

Carlos González Gartland (1931) graduated in law from the UBA. Originally a member of the Socialist Party, he joined the Gremial, where he met Eduardo Luis Duhalde and Rodolfo Mattarollo. He participated in the creation of the PROA in 1975. After the 1976 coup, he left for Mexico and became head of the local CADHU branch. Back in Argentina in 1983, he collaborated to several leftist journals. Together with Duhalde, he created the IRI and the IDEPO. He kept working as a lawyer in the 1980s and 1990s and became a consultant for the Secretariat of State for Human Rights when Duhalde was appointed in 2003.

Rodolfo Mattarollo (1939 - 2014) graduated in law from the UBA. He became involved with the PRT-ERP in the early 1970s and run one of the reviews of the party (Nuevo Hombre). He joined the Gremial, where he met Duhalde and González Gartland. In 1975, he relocated in Paris to organize international solidarity on behalf of the PRT-ERP. After 1976, he joined the CADHU and became head of its French branch. Back in Argentina in 1983, he worked as a journalist for several magazines, and became head of the cultural supplement of newspaper Nuevo Sur in 1989. In parallel, he joined the IRI and gave history classes to IDEPO youth activists. In the 1990s, he worked as a juridical consultant 
for NGOs and international organizations. When Duhalde was appointed Secretary of State for Human Rights in 2003, he became his chief of staff and then Sub-Secretary ${ }^{74}$.

${ }^{74}$ Biographical information on Duhalde, González Gartland and Mattarollo is based on archival work and interviews realized during my doctoral research: David Copello, L'Usage Politique des Droits de l'Homme: Trajectoires Militantes et Répertoires Discursifs des Nouvelles Gauches Argentines (1971 - 2012) (Paris: Institut d'Études Politiques de Paris, 2017). 